\title{
Pemodelan Geographically Weighted Logistic Regression dengan Fungsi Adaptive Gaussian Kernel Terhadap Kemiskinan di Provinsi NTT
}

\author{
Novia Amilatus Solekha $^{1^{*}}$, Mohammad Farhan Qudratullah ${ }^{2}$ \\ ${ }^{12}$ Depertemen Matematika, Fakultas Sains dan Teknologi, UIN Sunan Kalijaga Yogyakarta, \\ Jl. Laksada Adisucipto, Yogyakarta 55281, Indonesia \\ * Penulis Korespondensi. Email: Noviasolekhah51@mail.com
}

\section{ABSTRAK}

Model Geographically Weighted Logistic Regression (GWLR) merupakan pengembangan model regresi logistik yang diaplikasikan pada data spasial dari proses non stasioner. Model ini digunakan untuk memprediksi data dengan variabel respons biner yang dipengaruhi oleh faktor spasial. Penelitian ini akan membahas tentang penggunaan model GWLR dengan menggunakan fungsi pembobot adaptive gaussian kernel pada studi kasus kemiskinan di Provinsi Nusa Tenggara Timur pada tahun 2019. Penaksiran parameter model GWLR menggunakan metode Maximum Likelihood Estimation (MLE) dengan memberikan pembobot yang berbeda di setiap lokasi pengamatan. Pembobot yang digunakan adalah adaptive gaussian kernel dengan pemilihan bandwidth optimum menggunakan kriteria Cross-Validation (CV). Berdasarkan hasil pengujian parameter model GWLR dengan pembobot adaptive gaussian kernel, dapat disimpulkan bahwa faktor-faktor yang berpengaruh terhadap kemiskinan bersifat lokal dan berbeda-beda di 22 lokasi pengamatan, antara lain PDRB per kapita, penerimaan program Indonesia pintar, dan proyeksi laju pertumbuhan penduduk,dengan tingkat ketepatan klasifikasi $81,82 \%$.

\section{Kata Kunci:}

Adaptive Gaussian Kernel; GWLR; Kemiskinan; MLE, Regresi Logistik

\section{ABSTRACT}

The Geographically Weighted Logistic Regression (GWLR) model is a logistic regression model development that is applied to spatial data from non-stationary processes. This model is used to predict a model of the data set that has a binary response variable which takes into account the spatial factor. This study will discuss the use of the GWLR model using the adaptive weighting function of the Gaussian kernel in a poverty case study in East Nusa Tenggara Province in 2019.The parameter estimation of the Maximum Likelihood Estimation (MLE) method by giving different weights for each observation location. The weight used is the adaptive Gaussian kernel with the optimum bandwidth selection using the Cross-Validation (CV). Based on the results of testing the parameters of the GWLR model with a weighted adaptive Gaussian kernel, it can be concluded that the factors that influence poverty are local and vary in the 22 observation locations, including GRDP per capita, acceptance of smart Indonesian programs, and projected population growth rates, with a classification accuracy rate of $81,82 \%$.

\section{Keywords:}

Adaptive Gaussian Kernel; GWLR; Logistic Regression; MLE; Poverty 
Format Sitasi:

N. A. Solekha and M.F. Qudratullah, "Pemodelan Geographically Weighted Logistic Regression dengan Fungsi Adaptive Gaussian Kernel terhadap Kemiskinan Provinsi di NTT," Jambura J. Math., vol. 4, no. 1, pp.17-32, 2022, doi: https://doi.org/10.34312/jjom.v4i1.11452

\section{Pendahuluan}

Analisis Regresi merupakan alat analisis statistik yang memanfaatkan hubungan antara dua variabel atau lebih, tujuannya adalah membuat perkiraan atau prediksi yang dapat dipercaya untuk nilai suatu variabel respons jika nilai variabel prediktor diketahui [1]. Model regresi biasanya memiliki variabel respons bersifat kontinu atau diskrit, jika variabel respons yang bersifat diskrit atau kategori dapat dianalisis menggunakan analisis regresi logistik [2]. Analisis regresi logistik pada umumnya digunakan ketika unit pengamatan bukan merupakan wilayah atau lokasi, karena model tersebut tidak memperhitungkan wilayah atau lokasi. Masalah utama jika analisis ini diterapkan pada data yang mengandung informasi lokasi geografis atau spasial, maka akan terjadi heterogenitas spasial [3].

Heterogenitas spasial merupakan keadaan dimana variabel prediktor yang sama memberikan respons yang tidak sama pada lokasi yang berbeda dalam suatu wilayah penelitian. Terjadinya heterogenitas spasial pada parameter regresi menyebabkan analisis regresi global tidak memberikan efek lokal dari karakteristik yang ditimbulkan pada setiap lokasi atau geografis suatu wilayah [4]. Metode yang dapat mengatasi keheterogenan spasial adalah model Geographically weighted regression (GWR).

Model GWR adalah suatu metode yang membawa kerangka dari model regresi klasik menjadi regresi terboboti. Pendekatan yang dilakukan dalam GWR adalah pendekatan titik, setiap nilai parameter dihitung pada setiap titik wilayah geografis, sehingga setiap wilayah geografis memiliki nilai parameter yang berbeda [5]. Model GWR pada data respons dikotomi yang memuat heterogenitas spasial disebut dengan Geographically Weighted Logistic Regression (GWLR).

Model GWLR merupakan metode non parametrik yaitu suatu pengembangan dari metode regresi logistik dengan mempertimbangkan faktor lokasi, dimana lokasi diperhatikan dan diasumsikan bahwa data variabel respons berdistribusi Bernoulli [3]. Penaksiran parameter model GWLR dilakukan pada setiap lokasi pengamatan dengan menggunakan pembobot spasial yang ditentukan menggunakan fungsi pembobot. Fungsi pembobot yang dipilih adalah adaptive gaussian kernel. Fungsi ini dipilih karena pembobot yang digunakan pada model sesuai dengan kondisi titik pengamatan dan menghasilkan nilai bandwidth yang konstan atau berbeda-beda pada setiap lokasi pengamatan [6].

Beberapa penelitian sebelumnya tentang GWLR telah dilakukan diantaranya oleh Atkinson dkk. [7] yang mengkaji tentang hubungan antara erosi sungai dengan beberapa variabel yang memengaruhi erosi di sungai Dyfi Afon West Wales, Fathurahman dkk. [2] menganalisis Indeks Pembangunan Kesehatan Masyarakat di Provinsi Papua. Menunjukan bahwa model GWLR lebih efektif untuk pemodelan regresi pada data spasial dan lebih baik daripad model regresi global.

Kemiskinan merupakan salah satu fenomena keheterogenan spasial, hal ini dapat ditunjukkan dengan kondisi ekonomi yang bervariasi pada masing-masing daerah. Tingkat kemiskinan pada suatu daerah sering disebabkan oleh faktor-faktor dengan 
dimensi spasial, seperti letak geografis, tingkat pendidikan, serta laju pertumbuhan penduduk pada setiap daerah yang beragam [8]. Data kemiskinan dikumpulkan berdasarkan unit administratif seperti provinsi, kabupaten/kota yang berada pada ruang geografis. Data kemiskinan merupakan data spasial non stasioner dalam parameter yang bervariasi secara wilayah [9].

Tahun 2019, terdapat tiga provinsi dengan tingkat kemiskinan cukup tinggi di Indonesia yaitu Papua, Papua Barat dan Nusa Tenggara Timur (NTT). Mengingat pentingnya pengentasan kemiskinan serta persentase penduduk miskin yang masih tinggi di NTT, yaitu sebesar 1.153.760 jiwa pada maret 2019, dan mengalami peningkatan sebesar 24,3 ribu orang pada September 2019 atau 21,09 persen penduduk NTT tergolong miskin [10].

Penelitian tentang tingkat kemiskinan di NTT menggunakan analisis data panel telah dilakukan oleh Amelia dan Rindayati [11] menggunakan data time series periode 20042010 dengan cross section 15 kabupaten/kota. Serta Hatta dan Khoirudin [12] menggunakan data time series periode 2011-2017 dengan cross section 22 kabupaten/kota. Menunjukan bahwa penelitian sebelumnya hanya mengidentifikasi faktor-faktor yang memengaruhi kemiskinan di Provinsi NTT, belum mengidentifikasi faktor-faktor yang memengaruhi untuk setiap kabupaten/kota yang memeiliki kehetrogenan spasial. Pada penelitian ini model GWLR akan diaplikasikan pada data kemiskinan di Provinsi NTT pada tahun 2019.

Sejauh yang peneliti ketahui, analisis terkait kemiskinan di NTT yang menggunakan GWLR belum pernah dilakukan, khususnya analisis yang menggunakan software $\mathrm{R}$ Studio 4.0.3 dan ArcGIS 10.3. Maka pada penelitian ini akan menganalisis faktor-faktor yang memengaruhi kemiskinan secara spasial Provinsi NTT, sehingga diperoleh model GWLR yang mampu mengidentifikasi faktor-faktor yang memengaruhi kemiskinan untuk setiap 22 kabupaten/kota di Provinsi NTT pada tahun 2019.

\section{Metode}

Data yang digunakan dalam penelitian ini adalah data sekunder yang didapat dari publikasi Badan Pusat Statistik Provinsi NTT tahun 2019 yang meliputi 22 kabupaten/kota. Variabel yang digunakan dalam penelitian ini merupakan peubah respons bersifat biner yaitu dengan mengelompokkan kabupaten/kota menjadi miskin/tidak miskin, pengelompokan ini berdasarkan persentase penduduk yang berada dibawah Garis Kemiskinan (GK) berupa nilai Head Count Index (HCI) Provinsi NTT pada Maret 2019 yaitu sebesar 21,09\% [10].

Pada penelitian ini dikategorikan bahwa kabupaten/ kota didefinisikan miskin (=1), jika nilai proporsi kemiskinan (HCI) sama atau diatas angka provinsi NTT tahun 2019 sebesar 21,09\%, dan kabupaten/kota didefinisikan tidak miskin $(=0)$, jika nilai proporsi HCI dibawah angka provinsi NTT tahun 2019 sebesar 21,09\%. Variabel prediktor yang digunakan pada penelitian ini ada 6, yaitu Tingkat Partisipasi Angkatan Kerja [4], Produk Domestik Regional Bruto per Kapita, Proyeksi Laju Pertumbuhan Penduduk [13], Kepemilikan Aset Tanah [14], Penerimaan Program Indonesia Pintar [15], dan Ratarata Konsumsi Protein [16].

Adapun software yang digunakan adalah R Studio 4.0.3 untuk proses analisis data dan ArcGIS 10.3 untuk proses pembuatan peta dalam rangka interpretasi hasil. 


\subsection{Model Regresi Logistik}

Secara umum, model regresi logistik yang melibatkan beberapa variabel prediktor $x$ dapat dituliskan sebagai berikut [17].

$$
\pi\left(x_{i}\right)=\frac{\exp \left(\boldsymbol{\beta}^{T} \boldsymbol{x}_{i}\right)}{1+\exp \left(\boldsymbol{\beta}^{T} \boldsymbol{x}_{i}\right)}
$$

dimana $\boldsymbol{\beta}^{T}:\left[\beta_{0}, \beta_{1}, \cdots, \beta_{k}\right]$ dan $\boldsymbol{x}_{i}:\left[1, x_{1}, x_{2}, \cdots, x_{k}\right]^{T}$ menyatakan vektor variabel prediktor. Model logistik merupakan model non linear, yang memerlukan transformasi agar menjadi fungsi linier, transformasi yang digunakan adalah transformasi logit dari $\pi\left(x_{i}\right)$ sehingga berdasarkan persamaan (1) diperoleh

$$
1-\pi\left(x_{i}\right)=\frac{1}{1+\exp \left(\beta_{0}+\beta_{1} x_{1 i}+\ldots+\beta_{k} x_{k i}\right)}
$$

Rasio antara $\pi\left(x_{i}\right)$ dan $1-\pi\left(x_{i}\right)$ dituliskan sebagai berikut:

$$
\begin{aligned}
\frac{\pi\left(x_{i}\right)}{1-\pi\left(x_{i}\right)} & =\frac{\exp \left(\beta_{0}+\beta_{1} x_{1 i}+\ldots+\beta_{k} x_{k i}\right)}{1+\exp \left(\beta_{0}+\beta_{1} x_{1 i}+\ldots+\beta_{k} x_{k i}\right)} / \frac{1}{1+\exp \left(\beta_{0}+\beta_{1} x_{1 i}+\ldots+\beta_{k} x_{k i}\right)} \\
& =\exp \left(\beta_{0}+\beta_{1} x_{1 i}+\ldots+\beta_{k} x_{k i}\right)
\end{aligned}
$$

Selanjutnya pada persamaan (3) dilakukan transformasi lnpada kedua ruas

$$
\ln \left[\frac{\pi\left(x_{i}\right)}{1-\pi\left(x_{i}\right)}\right]=\ln \left[\exp \left(\beta_{0}+\beta_{1} x_{1 i}+\ldots+\beta_{k} x_{k i}\right)\right]
$$

sehingga didapatkan model logit regresi logistik biner global adalah

$$
g\left(x_{i}\right)=\ln \left[\frac{\pi\left(x_{i}\right)}{1-\pi\left(x_{i}\right)}\right]=\boldsymbol{\beta}^{T} \boldsymbol{x}_{i}
$$

\subsection{Uji Heterogenitas}

Uji heterogenitas diperlukan dalam rangka mengetahui adanya keragaman spasial pada pengamatan. Adanya heterogenitas spasial dapat menunjukkan bahwa data dapat dimodelkan dengan GWLR [18]. Disebut juga dalam uji Breusch-Pagan, adapun rumusan hipotesisnya:

$$
\begin{aligned}
& H_{0}: \sigma_{1}{ }^{2}=\sigma_{2}{ }^{2}=\ldots=\sigma_{i}{ }^{2} \\
& H_{1}: \text { minimal ada satu } \sigma_{i}{ }^{2} \neq \sigma^{2}
\end{aligned}
$$

Statistik uji:

$$
B P=\frac{1}{2} \boldsymbol{f}^{T} \boldsymbol{Z}\left(\boldsymbol{Z}^{T} \boldsymbol{Z}\right)^{-1} \boldsymbol{Z}^{T} \boldsymbol{f} \sim \chi_{k}^{2}
$$


dimana $\boldsymbol{f}:\left(f_{1}, f_{2}, \cdots, f_{n}\right)^{T}$ dan $\boldsymbol{Z}$ : merupakan matriks $n \times k$ variabel prediktor yang sudah distandarkan. Keputusan uji adalah Tolak $H_{0}$ jika $B P>\chi_{k}^{2}$ atau $P_{\text {value }}<\alpha$ dengan $k$ adalah banyaknya variabel prediktor.

\subsection{Model GWLR}

Bentuk umum model GWLR wilayah ke- $i$ secara matematis dapat ditulis sebagai berikut [7].

$$
\pi\left(\boldsymbol{x}_{i}\right)=\frac{\exp \left(\boldsymbol{\beta}^{T}\left(u_{i}, v_{i}\right) \boldsymbol{x}_{i}\right)}{1+\exp \left(\boldsymbol{\beta}^{T}\left(u_{i}, v_{i}\right) \boldsymbol{x}_{i}\right)}
$$

dengan $u_{i}$ menyatakan letak garis lintang (latitude) dan $v_{i}$ menyatakan letak garis bujur (longitude).

Untuk mendapatkan model GWLR yang linier terhadap parameternya, dilakukan transformasi logit terhadap persamaan (7) sehingga diperoleh model logit GWLR sebagai berikut:

$$
g\left(x_{i}\right)=\ln \left(\frac{\pi\left(\boldsymbol{x}_{i}\right)}{1-\pi\left(\boldsymbol{x}_{i}\right)}\right)=\left(\boldsymbol{\beta}^{T}\left(u_{i}, v_{i}\right) \boldsymbol{x}\right)
$$

Penaksiran parameter diperoleh dengan memaksimumkan fungsi logaritma natural likelihood dengan cara menurunkan $\beta\left(u_{i}, v_{i}\right)$ dan hasilnya disamadengankan nol. Diperoleh fungsi likelihood dengan variabel respons berdistribusi Bernoulli sebagai berikut 0:

$$
L\left(\boldsymbol{\beta}\left(u_{i}, v_{i}\right)\right)=\prod_{j=1}^{n} \prod_{i=1}^{n}\left[\sum_{i=1}^{n}\left(\pi\left(x_{i}\right)\right)^{y_{j}}\left(1-\pi\left(x_{i}\right)\right)^{1-y_{j}}\right]
$$

dengan demikian maka diperoleh fungsi log likelihood adalah

$$
\begin{aligned}
& \ln L\left(\boldsymbol{\beta}\left(u_{i}, V_{i}\right)\right)=\prod_{j_{\bar{\pi}_{1}} 1}^{n} \prod_{i_{i=1} 1}^{n}\left[\sum_{i=1}^{n}\left(\pi\left(x_{i}\right)\right)^{y_{j}}\left(1-\pi\left(x_{i}\right)\right)^{1-y_{j}}\right] \\
& =\sum_{j_{\bar{n}} 1}^{j_{\bar{\pi} 1} \sum_{\bar{n}_{1}} \sum_{i=1} 1}\left[y_{j} g\left(x_{i}\right)-\right] \ln \left(1+\left(\exp \left(g\left(x_{i}\right)\right)\right)\right) \\
& =\sum_{j=i}^{j_{\bar{n}} 1} \sum_{i=1}^{T_{\bar{n} 1}^{1}}\left[y_{j}\left(\mathbf{x}_{i} \boldsymbol{\beta}^{T}\right)\left(u_{i}, V_{i}\right)-\ln \left(1+\exp \left(\mathbf{x}_{i} \boldsymbol{\beta}^{T}\right)\left(u_{i}, V_{i}\right)\right)\right]
\end{aligned}
$$

Pembobot diberikan pada fungsi ln likelihood dan hasilnya adalah disamakan dengan nol, sehingga diperoleh turunan pertama fungsi likelihood terhadap $\beta\left(u_{i}, v_{i}\right)$ adalah:

$$
\begin{aligned}
& \frac{\partial \ln L\left(\boldsymbol{\beta}\left(u_{i}, v_{i}\right)\right)}{\partial \boldsymbol{\beta}\left(u_{i}, v_{i}\right)}=\sum_{j=1}^{n} \sum_{i=1}^{n} w_{j}\left(u_{i}, v_{i}\right)\left[y_{j}\left(\mathbf{x}_{i} \boldsymbol{\beta}\right)\left(u_{i}, V_{i}\right)-\ln \left(1+\exp \left(\mathbf{x}_{i} \boldsymbol{\beta}\right)\left(u_{i}, v_{i}\right)\right)\right] \\
& =\sum_{j=1}^{n} \sum_{i=1}^{n} w_{j}\left(u_{i}, v_{i}\right) x_{i}\left[y_{j}-\frac{\exp \left(\mathbf{x}_{i} \boldsymbol{\beta}\right)}{1+\exp \left(\mathbf{x}_{i} \boldsymbol{\beta}\right)} x_{i}\right] \\
& =\sum_{j=1}^{j} \sum_{i=1}^{j} w_{j}\left(u_{i}, v_{i}\right) x_{i}=\left[y_{j}-\pi\left(x_{i}\right)\right]
\end{aligned}
$$


dengan demikian diperoleh bahwa:

$$
\frac{\partial \ln L(\boldsymbol{\beta})}{\partial \boldsymbol{\beta}}=\sum_{j=1}^{n} \sum_{i=1}^{n} w_{j}\left(u_{i}, v_{i}\right) x_{j}\left[y_{j}-\pi\left(x_{i}\right)\right]=0
$$

Fungsi pada persamaan (12) diperoleh fungsi yang tidak closed-form, maka untuk mendapatkan penaksir parameter model GWLR dapat digunakan pendekatan numerik. Salah satu pendekatan numerik yang dapat digunakan adalah iterasi Newton-Raphson, yang mana algoritma dalam iterasi Newton-Raphson membutuhkan perhitungan vektor gradien dan matriks Hessian, vektor gradien dinyatakan dalam bentuk umum:

$$
g\left(\boldsymbol{\beta}\left(u_{i}, v_{i}\right)\right)=\boldsymbol{X}^{T} \boldsymbol{W}\left(u_{i}, v_{i}\right)\left(\boldsymbol{y}-\boldsymbol{\pi}\left(u_{i}, v_{i}\right) x_{i}\right)
$$

Selanjutnya dicari matriks Hessian yang merupakan matriks turunan parsial orde kedua dari fungsi log-likelihood $\ln L\left(\boldsymbol{\beta}\left(u_{i}, v_{i}\right)\right)$ terhadap komponen vektor parameter $\left(\boldsymbol{\beta}\left(u_{i}, v_{i}\right)\right)$. Bentuk umum matriks Hessian model GWLR adalah:

$$
\begin{aligned}
\frac{\partial^{2} \ln L\left(\boldsymbol{\beta}\left(u_{i}, V_{i}\right)\right)}{\partial \boldsymbol{\beta}\left(u_{i}, V_{i}\right)} & =\sum_{j=1}^{n} \sum_{i=1}^{n} w_{j}\left(u_{i}, V_{i}\right) x_{i} y_{j}-w_{j}\left(u_{i}, V_{i}\right) x_{j} \pi\left(x_{i}\right) \\
& =\sum_{j=1}^{n} \sum_{i=1}^{n}\left(0-\frac{\exp \left(\mathbf{x}_{i} \boldsymbol{\beta}\right) X_{i} W_{j}\left(u_{i}, V_{i}\right) X_{i}}{1+\exp \left(\mathbf{x}_{i} \boldsymbol{\beta}\right)}\left(1-\frac{\exp \left(\mathbf{x}_{i} \boldsymbol{\beta}\right) X_{i} X_{i}}{1+\exp \left(\mathbf{x}_{i} \boldsymbol{\beta}\right)}\right)\right) \\
& =-\sum_{j=1}^{n} \sum_{i=1}^{n} \pi\left(X_{i}\right) X_{i} W_{j}\left(u_{i}, V_{i}\right) X\left(1-\pi\left(X_{i}\right)\right)
\end{aligned}
$$

matriks Hessian pada persamaan (14) dapat dinyatakan sebagai berikut:

$$
\boldsymbol{H}\left(\boldsymbol{\beta}\left(u_{i}, v_{i}\right)\right)=-\boldsymbol{X}^{T} \boldsymbol{W}\left(u_{i}, v_{i}\right) \boldsymbol{V}\left(u_{i}, v_{i}\right) \boldsymbol{X}
$$

Berdasarkan vektor gradien dan matriks Hessian yang masing-masing diperoleh pada persamaan (13) dan (14), maka iterasi Newton-Raphson dapat dijalankan untuk memperoleh penaksir parameter $\widehat{\boldsymbol{\beta}}\left(u_{i}, v_{i}\right)$, dengan algoritma sebagai berikut:

$$
\widehat{\boldsymbol{\beta}}^{(t+1)}\left(u_{i}, v_{i}\right)=\widehat{\boldsymbol{\beta}}^{(t)}\left(u_{i}, v_{i}\right)-\left[\boldsymbol{H}\left(\widehat{\boldsymbol{\beta}}^{(t)}\left(u_{i}, v_{i}\right)\right)\right]^{-1} \boldsymbol{g}\left(\widehat{\boldsymbol{\beta}}^{(t+1)}\left(u_{i}, v_{i}\right)\right)
$$

Proses iterasi dimulai dari penentuan nilai awal Iterasi dan berhenti ketika keadaan konvergen $\left|\widehat{\boldsymbol{\beta}}^{(t+1)}\left(u_{i}, v_{i}\right)-\widehat{\boldsymbol{\beta}}^{(t)}\left(u_{i}, v_{i}\right)\right| \leq \varepsilon$ dimana $\varepsilon$ bilangan yang sangat kecil (misal $10^{-15}$ ), dengan penaksir lokal model GWLR adalah $\widehat{\boldsymbol{\beta}}^{(t+1)}\left(u_{i}, v_{i}\right)$ pada saat iterasi terakhir. Selanjutnya dilakukan pengujian parameter pada model GWLR yang dilakukan secara serentak dan parsial.

Berikut disajikan pengujian secara serentak dengan hipotesis sebagai berikut:

$H_{0}: \beta_{1}\left(u_{i}, v_{i}\right)=\beta_{2}\left(u_{i}, v_{i}\right)=\cdots=\beta_{k}\left(u_{i}, v_{i}\right)=0$

$H_{i}$ : minimal terdapat satu $\beta_{k}\left(u_{i}, v_{i}\right) \neq 0, k=1,2, \cdots, p ; i=1,2, \cdots, n$ 
Statistik uji:

$$
G_{2}=2\left(\ln L\left(\widehat{\Omega}_{G W L R}\right)-\ln L\left(\widehat{\omega}_{G W L R}\right)\right)
$$

dimana

$$
\ln L\left(\hat{\Omega}_{G W L R}\right)=\sum_{i=1}^{n}\left(y_{i} \ln \left(\hat{\pi}_{i}\right)+\ln \left(1-y_{i}\right)\left(1-\hat{\pi}_{i}\right)\right)
$$

kriteria pengujian adalah tolak $H_{0}$ jika nilai $G_{2}>\chi_{(\alpha ; v)}^{2}$ atau $p$ value $<\alpha$

Sedangkan pengujian parameter GWLR secara parsial dengan hipotesis sebagai berikut:

$H_{0}: \beta_{k}\left(u_{i}, v_{i}\right)=0$.

$H_{i}$ : minimal terdapat satu $\beta_{k}\left(u_{i}, v_{i}\right) \neq 0$

Statistik uji:

$$
Z_{k}=\frac{\hat{\beta}_{k}\left(u_{i}, v_{i}\right)}{S E\left(\hat{\beta}_{k}\left(u_{i}, v_{i}\right)\right)}
$$

Kriteria pengujian adalah tolak $H_{0}$ jika nilai $\left|Z_{k}\right|>Z_{\frac{\alpha}{2}}$ atau $p$ value $<\alpha$, dimana $Z$ adalah variabel acak berdistribusi normal baku dan $Z_{k}$ adalah nilai statistik uji wald, maka $H_{0}$ ditolak, sehingga garis regresi tidak melalui titik pusat [2].

\subsection{Fungsi Adaptive Gaussian Kernel}

Fungsi adaptive gaussian kernel merupakan salah satu fungsi pembobot dalam model GWRL. Peran pembobotan sangat penting karena nilai pembobotan ini mewakili letak data observasi satu terhadap lainnya, pembobot spasial dihitung menggunakan fungsi pembobot yang bergantung pada jarak antar lokasi $\left(u_{i}, v_{i}\right)$ dengan lokasi $\left(u_{j}, v_{j}\right)$ disimbolkan dengan $d_{i j}$ dan dihitung menggunakan rumus jarak Euclidean [19].

$$
d_{i j}=\sqrt{\left(u_{i}, u_{j}\right)^{2}+\left(v_{i}, v_{j}\right)^{2}}
$$

Misalkan $w_{i j}$ menyatakan pembobot spasial yang diberikan oleh pengamatan pada lokasi ke- $j$ untuk model GWR pada lokasi ke- $i(i=1,2, \cdots, n)$. Fungsi adaptive gaussian kernel secara umum ditulis:

$$
w_{j}=\left(u_{i}, v_{i}\right)=\exp \left(-\frac{1}{2}\left(\frac{d_{i j}}{b_{i(p)}}\right)^{2}\right)
$$

dengan $b$ menyatakan parameter penghalus, $b_{i(p)}$ menyatakan bandwidth adaptive yang menetapkan $p$ sebagai jarak lokasi ke- $i, h$ menyatakan parameter bandwidth ke- $i$ dan $d_{i j}$ ' menyatakan euclidean antar lokasi $\left(u_{i}, v_{i}\right)$ 


\subsection{Pemilihan Bandwidth Optimum dan Evaluasi Model}

Ada beberapa metode yang digunakan dalam memilih bandwidth optimum, salah satu diantaranya adalah metode Cross Validation (CV) yang dapat dirumuskan sebagai berikut [6]:

$$
C V=\sum_{i=1}^{n}\left(y_{i}-\hat{y}_{\neq i}(b)\right)^{2}
$$

Evaluasi model, dalam hal ini evaluasi fungsi klasifikasi dilakukan dengan membuat tabulasi antara actual group dan predicted group yang diperoleh dari fungsi logistik. Selanjutnya dihitung proporsi pengamatan yang benar klasifikasinya, diharapkan proporsi pengamatan yang benar diklasifikasikan tersebut sebesar mungkin atau proporsi pengamatan yang salah sekecil mungkin [20].

\section{Hasil dan Pembahasan}

\subsection{Deskripsi Kemiskinan di Provinsi NTT}

Data kemiskinan yang digunakan terdiri 21 kabupaten dan 1 kotamadya di Provinsi NTT. Pemilihan kriteria proporsi kemiskinan berdasarkan Head Count Index (HCI) kabupaten/kota di Provinsi NTT pada tahun 2019, yaitu sebesar 21,09\%. Dalam penelitian ini menggunakan enam peubah prediktor $(x)$ yang memengaruhi tingkat kemiskinan di Provinsi NTT.

Deskripsi dari keenam peubah prediktor yang digunakan dinyatakan dalam statistika deskriptif yang meliputi rata-rata nilai maksimum, nilai minimum, dan simpangan baku. Perhitungan statistika deskriptif menggunakan software $\mathrm{R}$ Studio 4.0.3 yang disajikan dalam tabel sebagai berikut:

Tabel 1. Statistika deskriptif data variabel prediktor

\begin{tabular}{lcccc}
\hline \multicolumn{1}{c}{ Variabel } & Rata-rata & Max & Min & $\begin{array}{c}\text { Simpangan } \\
\text { Baku }\end{array}$ \\
\hline Partisipasi angkatan kerja $\left(x_{1}\right)$ & 69,03 & 79,67 & 58,75 & 4,74 \\
PDRB per kapita $\left(x_{2}\right)$ & 0,98 & 6,26 & 4,230 & 0,35 \\
Kepemilikan Aset Tanah $\left(x_{3}\right)$ & 84,14 & 95,63 & 46,07 & 12,06 \\
Penerimaan program indonesia pintar $\left(x_{4}\right)$ & 20,33 & 35,06 & 4,16 & 8,14 \\
Proyeksi laju pertumbuhan penduduk $\left(x_{5}\right)$ & 1,22 & 1,34 & 0,98 & 0,09 \\
Rata-rata konsumsi protein $\left(x_{6}\right)$ & 53,29 & 63,48 & 45,34 & 5,18 \\
\hline
\end{tabular}

Adapun peta sebaran kemiskinan pada kabupaten/kota di Provinsi Nusa Tenggara Timur menggunakan variabel respons $(y)$ adalah sebagai berikut: 


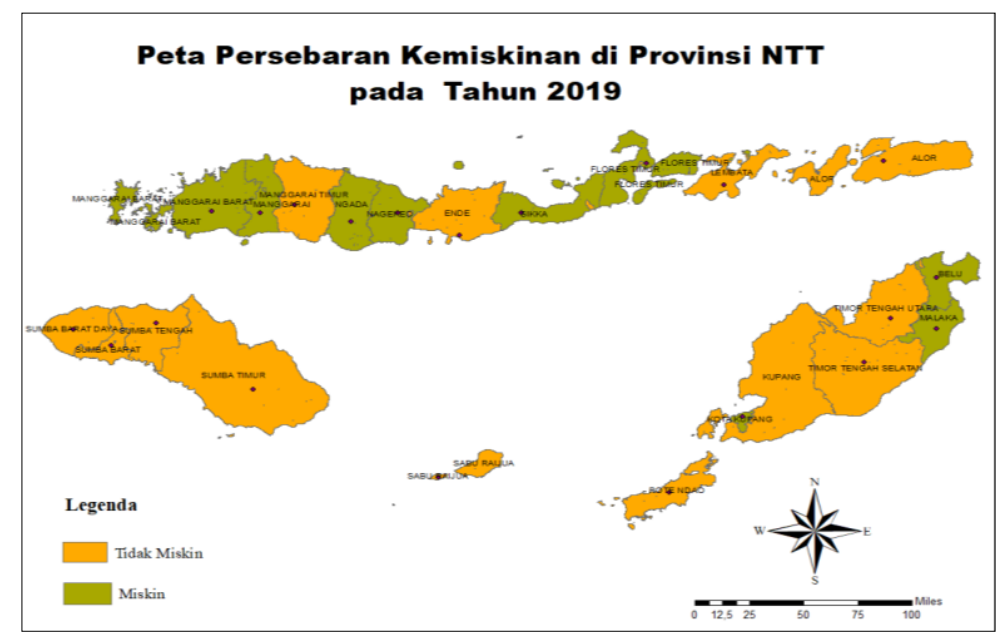

Gambar 1. Peta sebaran kemiskinan 22 kabupaten/kota provinsi NTT 2019

Berdasarkan Gambar 1 di atas diperoleh informasi bahwa:

- Warna coklat mengidentifikasi bahwa kabupaten/kota masuk dalam kategori proporsi kemiskinan (HCI) sama atau diatas angka provinsi NTT tahun 2019 sebesar 21,09\% yaitu Kabupaten/Kota Sumba Barat, Sumba Timur, Kupang, Timor Tengah Selatan, Timor Tengah Utara, Alor, Lembata, Ende, Rote Ndao, Sumba Tengah, Sumba Barat Daya, Manggarai Timur, dan Sabu Raijua.

- Sedangkan warna hijau mendeskripsikan kabupaten/kota masuk dalam kategori proporsi kemiskinan HCI dibawah angka provinsi NTT tahun 2019 sebesar 21,09\% yaitu Kabupaten/Kota Belu, Flores Timur, Sikka, Ngada, Manggarai, Manggarai Barat, Nagekeo, Malaka, dan Kota Kupang.

Kabupaten yang tergolong proporsi kemiskinan HCI dibawah angka provinsi (NTT tahun 2019 sebesar 21,09\% sebagian besar berada di pulau Flores dan sebagian di Pulau Timor yang berbatasan dengan Timor Leste.

\subsection{Pendeteksian Multikolinearitas}

Sebelum memodelkan dengan menggunakan regresi logistik biner dilakukan uji multikolinearitas terhadap variabel bebas untuk mengetahui adanya korelasi di antara variabel bebas. Hasil yang diperoleh adalah seperti Tabel 2.

Tabel 2. Nilai VIF variabel prediktor

\begin{tabular}{ccccccc}
\hline Variabel & $x_{1}$ & $x_{2}$ & $x_{3}$ & $x_{4}$ & $x_{5}$ & $x_{6}$ \\
\hline Nilai VIF & 4,241 & 1,939 & 3,391 & 1,233 & 1,712 & 3,310 \\
\hline
\end{tabular}

Berdasarkan nilai VIF pada Tabel 2. dapat disimpulkan bahwa tidak terjadi multikolinearitas antar variabel prediktor. Hal ini ditunjukkan nilai VIF setiap variabel kurang dari 10, sehingga semua prediktor dapat digunakan dalam pembentukan model regresi logistik biner. 


\subsection{Pemodelan kemiskinan dengan Regresi Logistik Biner}

Tahap pertama pemodelan GWLR pada kasus ini adalah melakukan pemodelan menggunakan regresi logistik biner. Hasil penaksiran parameter menggunakan software R Studio 4.0.3 ditunjukkan pada Tabel 3.

Tabel 3. Penaksiran parameter model regresi logistik biner

\begin{tabular}{cccccccc}
\hline Parameter & Intersep & $x_{1}$ & $x_{2}$ & $x_{3}$ & $x_{4}$ & $x_{5}$ & $x_{6}$ \\
Nilai & $-4,9703$ & $-0,6067$ & 0,0345 & 0,1262 & $-0,0492$ & 7,4952 & 0,5016 \\
Taksiran & & & & & & \\
\hline
\end{tabular}

Berdasarkan pada Tabel 3. didapatkan model global regresi logistik adalah sebagai berikut:

$$
\begin{aligned}
& \hat{\pi}\left(x_{i}\right) \\
& =\frac{\exp \left(-4,9703-0,6067 \mathrm{x}_{1}+0,0345 \mathrm{x}_{2}+0,1262 \mathrm{x}_{3}-0,0492 \mathrm{x}_{4}+7,4952 \mathrm{x}_{5}+0,5016 \mathrm{x}_{6}\right)}{1+\exp \left(-4,9703-0,6067 \mathrm{x}_{1}+0,0345 \mathrm{x}_{2}+0,1262 \mathrm{x}_{3}-0,0492 \mathrm{x}_{4}+7,4952 \mathrm{x}_{5}+0,5016 \mathrm{x}_{6}\right)}
\end{aligned}
$$

Model logistik merupakan model non linier, yang mana memerlukan transformasi agar menjadi fungsi linier, transformasi yang digunakan adalah transformasi logit dari $\pi\left(x_{i}\right)$ sehingga diperoleh:

$$
g\left(x_{i}\right)=-4,9703-0,6067 \mathrm{x}_{1}+0,0345 \mathrm{x}_{2}+0,1262 \mathrm{x}_{3}-0,0492 \mathrm{x}_{4}+7,4952 \mathrm{x}_{5}+0,5016 \mathrm{x}_{6}
$$

Berdasarkan pada model global regresi logistik didapatkan bahwa variabel yang berpengaruh signifikan terhadap proporsi tingkat kemiskinan di Provinsi NTT adalah PDRB Per Kapita $\left(x_{2}\right)$ dan variabel Penerimaan Program Indonesia Pintar $\left(x_{4}\right)$.

Selanjutnya untuk menyatakan kelayakan suatu model - hal ini dilakukan untuk mengukur seberapa besar persentase observasi diklasifikasikan secara tepat - dilakukan

\begin{tabular}{|c|c|c|c|}
\hline \multirow[b]{2}{*}{ Observasi } & \multicolumn{2}{|c|}{ Prediksi } & \multirow[b]{2}{*}{$\begin{array}{c}\text { Persentase Ketepatan } \\
\text { Klasifikasi }\end{array}$} \\
\hline & $\begin{array}{l}\text { Kabupaten/Kota } \\
\text { Tidak Miskin }\end{array}$ & $\begin{array}{c}\text { Kabupaten/Kota } \\
\text { Miskin }\end{array}$ & \\
\hline $\begin{array}{c}\text { Kabupaten/Kota } \\
\text { Tidak Miskin }\end{array}$ & 10 & 3 & $76,93 \%$ \\
\hline $\begin{array}{c}\text { Kabupaten/Kota } \\
\text { Miskin }\end{array}$ & 4 & 5 & $55,56 \%$ \\
\hline \multicolumn{3}{|c|}{ Persentase Keseluruhan } & $68,19 \%$ \\
\hline
\end{tabular}
uji ketepatan klasifikasi model sebagai berikut:

Tabel 4. Hasil uji ketepatan klasifikasi model logistik biner

Berdasarkan Tabel 4. Terlihat bahwa persentase ketepatan pengklasifikasian proporsi kemiskinan keseluruhan sebesar 68,19. Menunjukkan bahwa kabupaten/kota yang berstatus tidak miskin terklasifikasi dengan benar sebesar 76,93\%, serta kabupaten/kota yang berstatus miskin terklasifikasi dengan benar sesuai status kemiskinannya sebesar $55,56 \%$. Hal ini berarti dengan menggunakan model regresi logistik biner terdapat lima 
belas dari dua puluh dua kabupaten/kota di Provinsi NTT yang terklasifikasi dengan benar sesuai proporsi kemiskinannya.

\subsection{Uji Heterogenitas}

Tahap kedua adalah melakukan uji heterogenitas spasial menggunakan statistik uji Breusch-Pagan yang disajikan pada Tabel 5.

Tabel 5. Hasil uji asumsi heterogenitas spasial

\begin{tabular}{ccc}
\hline Uji Breusch-Pagan & Df & P-value \\
\hline 12,153 & 6 & 0,0586 \\
\hline
\end{tabular}

Berdasarkan Tabel 5. didapatkan bahwa nilai uji Breusch-Pagan adalah 12,153 $>\chi_{\text {tabel }}^{2}=$ 10,645 dan nilai $p_{\text {value }}=0,0586<\alpha(0,10)$ sehingga dapat diputuskan bahwa $H_{0}$ ditolak yang berarti varians antar lokasi berbeda atau terjadi heterogenitas, sehingga untuk kasus kemiskinan di provinsi NTT di atas perlu dilakukan pemodelan menggunakan GWLR.

\subsection{Pemodelan Kemiskinan dengan GWLR (Adaptive Gaussian Kernel)}

Pada tahap ketiga ini, langkah pertama yang dilakukan adalah menentukan letak geografis (longitude dan latitude) dengan batas wilayah kabupaten/kota dengan titik pengamatan adalah titik pusat pemerintahan di setiap kabupaten / kota di Provinsi NTT. Setelah menentukan letak geografis maka langkah selanjutnya menghitung jarak euclidean $\left(d_{i j}\right)$ antar lokasi $\left(u_{i}, v_{i}\right)$ dengan semua lokasi. Kemudian menentukan bandwidth optimum menggunakan metode Cross Validation (CV) yaitu sebesar 10,0769. Setelah mendapatkan jarak euclidean dan bandwidth optimum, maka diperoleh matriks pembobot yang digunakan untuk menduga parameter di wilayah $\left(u_{i}, v_{i}\right)$. Hasil ringkasan deskriptif dari penaksir model GWLR dapat dilihat pada Tabel 6. sebagai berikut:

Tabel 6. Ringkasan hasil estimasi parameter model gwlr

\begin{tabular}{cccccc}
\hline Variabel & Minimum & Kuartil 1 & Median & Kuartil 3 & Maksimum \\
\hline Intersep & $-10,561$ & 10,248 & 5,494 & 1,409 & $-0,953$ \\
$x_{1}$ & $-0,658$ & $-0,650$ & 0,621 & 0,567 & $-0,555$ \\
$x_{2}$ & $-0,452$ & $-0,424$ & 0,100 & 0,466 & 0,507 \\
$x_{3}$ & 0,116 & 0,118 & 0,131 & 0,139 & 0,141 \\
$x_{4}$ & $-0,080$ & $-0,078$ & 0,044 & 0,022 & $-0,020$ \\
$x_{5}$ & 6,338 & 6,866 & 8,829 & 9,542 & 9,733 \\
$x_{6}$ & 0,485 & 0,486 & 0,509 & 0,519 & 0,520 \\
\hline
\end{tabular}

Setelah diperoleh penaksir parameter model GWLR, langkah selanjutnya adalah melakukan pengujian secara serentak dan parsial. pengujian secara serentak bertujuan untuk untuk mengetahui pengaruh variabel prediktor terhadap variabel respons secara bersama-sama, dengan hipotesis sebagai berikut:

$H_{0}: \beta_{1}\left(u_{i}, v_{i}\right)=\beta_{2}\left(u_{i}, v_{i}\right)=\cdots=\beta_{22}\left(u_{i}, v_{i}\right)=0$

$H_{1}$ : minimal terdapat satu $\beta_{k}\left(u_{i}, v_{i}\right) \neq 0, k=1,2, \cdots, 6 ; i=1,2, \cdots, 22$ 
statistik uji yang digunakan adalah statistik uji $G_{2}$, dimana hasil pengujian serentak dapat dilihat pada Tabel 7.

Tabel 7. Hasil uji serentak model gwlr

\begin{tabular}{ccc}
\hline$G_{2}$ & $\chi^{2}{ }_{(0,1 ; 6)}$ & Keputusan Uji \\
\hline 13,69969 & 10,645 & Tolak $H_{0}$ \\
\hline
\end{tabular}

Berdasarkan Tabel 7. terlihat bahwa keputusan uji adalah menolak $H_{0}$ pada taraf signifikansi 0,10. Hal ini ditunjukkan oleh nilai statistik uji $G_{\text {hit }}=13,69969>$ $\chi_{\text {tabel(0.10;6) }}^{2}=10,645$, yang berarti minimal terdapat satu variabel prediktor memberikan pengaruh yang signifikan terhadap faktor-faktor yang memengaruhi kemiskinan untuk setiap kabupaten/kota di Provinsi NTT pada tahun 2019.

Pengujian hipotesis selanjutnya adalah pengujian secara parsial yang bertujuan untuk mengetahui pengaruh variabel prediktor secara individu terhadap variabel respons, dengan hipotesis sebagai berikut:

$H_{0}: \beta_{k}\left(u_{i}, v_{i}\right)=0$

$H_{1}$ : Minimal terdapat satu $\beta_{k}\left(u_{i}, v_{i}\right) \neq 0$

Sebagai ilustrasi, Tabel 8. menunjukkan salah satu hasil estimasi dan pengujian parsial untuk salah satu kabupaten/ kota, yaitu kabupaten Sumba Barat:

Tabel 8. Pengujian hipotesis parameter model gwlr secara parsial untuk kabupaten Sumba Barat

\begin{tabular}{cccc}
\hline Variabel & Nilai Taksiran & Standar Eror & $Z_{\text {hit }}$ \\
\hline Intersep & $-1,049$ & 6,192 & $-0,017$ \\
$x_{1}$ & $-0,648$ & 0,654 & $-0,992$ \\
$x_{2}$ & $-0,436$ & 0,070 & $-6,191$ \\
$x_{3}$ & 0,139 & 0,487 & 0,286 \\
$x_{4}$ & $-0,021$ & 0,003 & $-7,770$ \\
$x_{5}$ & 6,364 & 3,576 & 1,780 \\
$x_{6}$ & 0,518 & 1,486 & 0,349 \\
\hline
\end{tabular}

Berdasarkan Tabel 8, variabel prediktor yang berpengaruh secara individu terhadap faktor-faktor yang memengaruhi penduduk kota miskin di Kabupaten Sumba Barat adalah PDRB per kapita $\left(x_{2}\right)$, penerimaan program Indonesia pintar $\left(x_{4}\right)$, dan proyeksi laju pertumbuhan penduduk $\left(x_{5}\right)$. Hal ini ditunjukkan dari nilai $Z_{h i t}>Z_{(0,05)}=1,64$. Sehingga didapatkan model GWLR pembobot adaptive gaussian kernel di Kabupaten Sumba Barat adalah:

$$
\hat{\pi}(\boldsymbol{x})=\frac{\exp \left(-1,049-0,437 \mathrm{x}_{2}-0,021 \mathrm{x}_{4}+6,364 \mathrm{x}_{5}\right)}{1+\exp \left(-1,049-0,437 \mathrm{x}_{2}-0,021 \mathrm{x}_{4}+6,364 \mathrm{x}_{5}\right)}
$$

Model transformasi logit adalah:

$$
g(\boldsymbol{x})=-1,049-0,437 \mathrm{x}_{2}-0,021 \mathrm{x}_{4}+6,364 \mathrm{x}_{5}
$$


Dengan cara yang sama untuk 22 kota/ kabupaten di Provinsi NTT Berdasarkan output software $\mathrm{R}$ Studio 4.0.3 diperoleh faktor- faktor yang signifikan memengaruhi kemiskinan di Provinsi NTT tahun 2019, dapat dikelompokkan menjadi 4, seperti yang disajikan dalam Tabel 9. dan Gambar 2.

Penelitian yang sama mengenai kemiskinan di Provinsi NTT juga dilakukan oleh Hatta dan Khoirudin [12] dengan pendekatan Data Panel yang menghasilkan faktor-faktor signifikansi tingkat kemiskinan untuk Provinsi NTT secara umum. Adapun penelitian yang dilakukan penulis menggunakan metode GWLR dengan pembobot adaptive gaussian kernel menghasilkan faktor-faktor signifikansi proporsi tingkat kemiskinan secara lebih spesifik untuk setiap kabupaten/kota di NTT.

Hasil pengelompokan kabupaten/kota berdasarkan variabel-variabel yang signifikan dalam model GWLR seperti pada Tabel 9. dan Gambar 2.

Tabel 9. Pengelompokan kabupaten/kota di provinsi NTT berdasarkan faktor-faktor yang mempengaruhi kemiskinan dengan model GWLR

\begin{tabular}{|c|c|}
\hline Kabupaten/Kota & Faktor atau Variabel yang Signifikan \\
\hline $\begin{array}{l}\text { Sumba Timur, Sumba Tengah, Sumba } \\
\text { Barat, Sumba Barat Daya, Manggarai } \\
\text { Barat, Manggarai, Manggarai Timur, } \\
\text { Ngada, Nagekeo }\end{array}$ & $\begin{array}{l}\text { PDRB per kapita }\left(x_{2}\right) \text {, penerimaan } \\
\text { program Indonesia pintar }\left(x_{4}\right) \text {, dan } \\
\text { proyeksi laju pertumbuhan penduduk } \\
\left(x_{5}\right)\end{array}$ \\
\hline Rote Ndao & $\begin{array}{l}\text { PDRB per kapita }\left(x_{2}\right) \text {, dan penerimaan } \\
\text { program Indonesia pintar }\left(X_{4}\right)\end{array}$ \\
\hline Sabu Raijua & $\begin{array}{l}\text { PDRB per kapita }\left(x_{2}\right) \text {, dan proyeksi laju } \\
\text { pertumbuhan penduduk }\left(X_{5}\right)\end{array}$ \\
\hline $\begin{array}{l}\text { Sikka, Flores Timur, Lembata, Alor, Belu, } \\
\text { Malaka, Timor Tengah Utara, Timor } \\
\text { Tengah Selatan, Kupang, Kota Kupang }\end{array}$ & PDRB per kapita $\left(X_{2}\right)$ \\
\hline
\end{tabular}

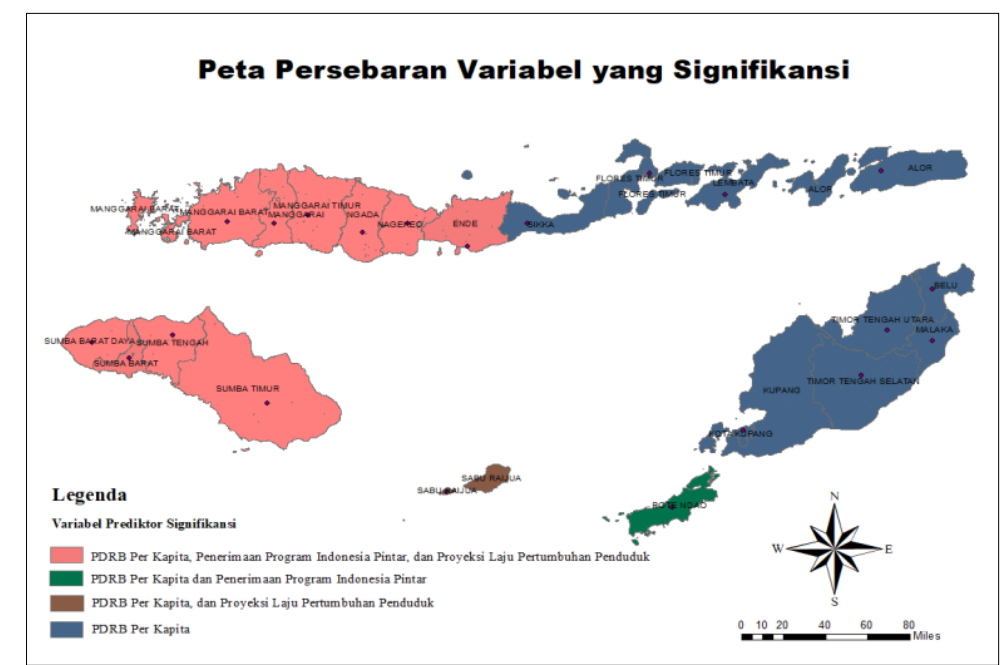

Gambar 2. Peta signifikansi faktor-faktor yang memengaruhi kemiskinan pada 22 kabupaten/kota provinsi NTT tahun 2019.

Berdasarkan Tabel 9 dan Gambar 2 dapat dijelaskan faktor-faktor yang memengaruhi kemiskinan di 22 Kabupaten/Kota Provinsi NTT tahun 2019 menggunakan model GWLR fungsi adaptive gaussian kernel sebagai berikut: 
1. Warna merah muda pada peta mengindikasikan bahwa proporsi kemiskinan pada Kabupaten/Kota Sumba Barat, Sumba Timur, Ende, Ngada, Manggarai, Manggarai Barat, Sumba Tengah, Sumba Barat Daya, Nagekeo dan Manggarai Timur dipengaruhi oleh PDRB per kapita, penerimaan program Indonesia pintar, dan proyeksi laju pertumbuhan penduduk.

2. Warna hijau pada peta mengindikasikan bahwa proporsi kemiskinan pada Kabupaten Rote Ndao dipengaruhi oleh PDRB per kapita, dan penerimaan Program Indonesia pintar.

3. Warna coklat pada peta mengindikasikan bahwa proporsi kemiskinan pada Kabupaten Sabu Raijua dipengaruhi oleh PDRB per kapita, dan proyeksi laju pertumbuhan penduduk.

4. Warna biru dongker pada peta mengindikasikan bahwa proporsi kemiskinan pada Kabupaten/Kota Kupang, Timor Tengah Selatan, Timor Tengah Utara, Belu, Alor, Lembata, Flores Timur, Sikka, Malaka, dan Kota Kupang dipengaruhi oleh PDRB per kapita.

Penelitian ini diperkuat oleh Mustika [13] yang menyatakan bahwa PDB dan jumlah penduduk berpengaruh positif terhadap kemiskinan. Serta penelitian yang dilakukan Maliangga dkk. [15] yang menyatakan bahwasannya program Kartu Indonesia Pintar (KIP) dan Kartu Indonesia Sehat (KIS) memberikan dampak positif terhadap percepatan penanggulangan kemiskinan pada rumah tangga miskin.

\subsection{Uji Ketepatan Klasifikasi Model GWLR}

Berikut disajikan tabel ketepatan klasifikasi model GWLR dengan fungsi pembobot adaptive gaussian kernel:

Tabel 10. Uji ketepatan klasifikasi model gwlr adaptive gaussian kernel

\begin{tabular}{|c|c|c|c|}
\hline \multirow[b]{2}{*}{ Observasi } & \multicolumn{2}{|c|}{ Prediksi } & \multirow[b]{2}{*}{$\begin{array}{c}\text { Persentase Ketepatan } \\
\text { Klasifikasi }\end{array}$} \\
\hline & $\begin{array}{c}\text { Kabupaten/Kota } \\
\text { Tidak Miskin }\end{array}$ & $\begin{array}{c}\text { Kabupaten/Kota } \\
\text { Miskin }\end{array}$ & \\
\hline $\begin{array}{c}\text { Kabupaten/Kota } \\
\text { Tidak Miskin }\end{array}$ & 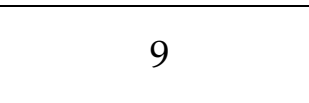 & 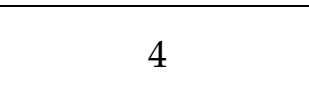 & $69,24 \%$ \\
\hline $\begin{array}{c}\text { Kabupaten/Kota } \\
\text { Miskin }\end{array}$ & 0 & 9 & $100,00 \%$ \\
\hline \multicolumn{3}{|c|}{ Persentase Keseluruhan } & $81,82 \%$ \\
\hline
\end{tabular}

Berdasarkan Tabel 10. menjelaskan persentase ketepatan klasifikasi proporsi kemiskinan kabupaten/kota di Provinsi NTT menggunakan model GWLR dengan pembobot adaptive gaussian kernel sebesar $81,82 \%$. Hal ini berarti delapan belas dari dua puluh dua kabupaten/kota di Provinsi NTT yang terklasifikasi dengan benar sesuai proporsi kemiskinannya. Sehingga model GWLR lebih baik digunakan untuk menganalisis kemiskinan di Provinsi NTT dibandingkan dengan model regresi logistik biner, penelitian ini diperkuat oleh Fathurahman dkk. [2] dan Dwinata [9] menghasilkan bahwasanya model GWLR memberikan persentase seluruh observasi terklasifikasi dengan benar yang lebih tinggi. Secara visual dapat disajikan dalam Gambar 3. 


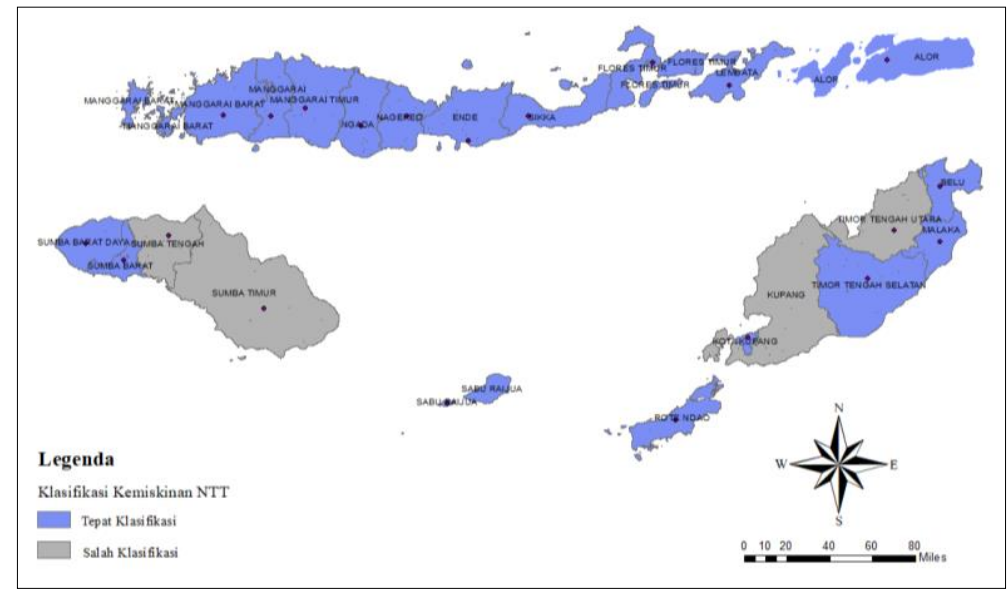

Gambar 3. Peta Misklasifikasi proporsi kemiskinan kabupaten/kota berdasarkan model GWLR

Pada Gambar 3. didapatkan peta misklasifikasi proporsi kemiskinan bahwa terdapat empat kabupaten/kota di Provinsi NTT yang berstatus tidak miskin akan tetapi hasil prediksi mengategorikan miskin yaitu Kabupaten Sumba Timur, Sumba Tengah, Kupang, dan Timor Tengah Utara.

\section{Kesimpulan}

Berdasarkan hasil estimasi dan pengujian hipotesis model GWLR dengan pembobot adaptive gaussian kernel dihasilkan 22 model yang terbagi menjadi empat kelompok berdasarkan faktor-faktor yang memengaruhi kasus kemiskinan di Provinsi NTT tahun 2019 yaitu variabel PDRB per kapita, penerimaan Program Indonesia Pintar, dan proyeksi laju pertumbuhan penduduk. Model GWLR dengan pembobot adaptive gaussian kernel lebih baik digunakan dalam memodelkan kemiskinan di Provinsi NTT pada tahun 2019 daripada model regresi logistik biner karena memiliki tingkat persentase ketepatan klasifikasi yang lebih tinggi, yaitu sebesar $81,82 \%$.

\section{Referensi}

[1] M. F. Qudratullah, Analisis Regresi Terapan: Teori, Contoh Kasus dan Aplikasi dengan SPSS, (Ed.1). Yogyakarta: CV Andi Offset, 2013.

[2] M. Fathurahman, Purhadi, Sutikno, and V. Ratnasari, "Pemodelan Geographically Weighted Logistic Regression pada Indeks Pembangunan Kesehatan Masyarakat di Provinsi Papua," in Prosiding Seminar Nasional MIPA, 2016, pp. 34-42.

[3] F. D. Lestari, Kusnandar. D, and N. N. Debataraja, "Estimasi Parameter Model Geographically Weighted Logistic Regression," Buletin Ilmiah Mat.Stat. dan Terapannya (Bimaster)., vol. 09, no. 1, pp.159-164, 2020.

[4] Wulandari, "Geographically Weighted Logistic Regression dengan Fungsi Kernel Fixed Gaussian pada Kemiskinan Jawa Tengah," Indonesian Journal of Statistics and its Application, vol.2. no. 2, pp.101-112, Nov. 2018.

[5] A. S. Fotheringham, C. Brunsdon, and M. E. Charlton, "Geographically Weighted Regression: The Analysis of Spatial Varying Relationship". Chichester: John Wiley dan Sons Ltd. 2002. 
[6] R. E. Caraka, and H. Yasin, Geographically Weighted Regression (GWR); Sebuah Pendekatan Regresi Geografis, (Ed.1. Cet. Ke - 1). Yogyakarta: Mobius,2017.

[7] P. M. Atkinson, S. E. German, D.A. Sear, and M. J. Clark, "Exploring The Relations Between Riverbank Erosion And Geomorphological Controls Using Geographically Weighted Logistic Regression". Ohio State University, Ohio 2003.

[8] N. Meilani, "Model Regresi Logistik Terboboti Geografis Menggunakan Kernel Gaussian dan Kernel Bisquare," Universitas Gadjah Mada, Yogyakarta, 2017.

[9] A. Dwinata, "Model Regresi Logistik Terboboti Geografis,"Institut Pertanian Bogor, Bogor, 2012.

[10] BPS, "Indikator Ekonomi Provinsi Nusa Tenggara Timur 2019". Nusa Tenggara Timur: Badan Pusat Statistik, 2019.

[11] R. Amelia and W. Rindayati, "Analisis Faktor-faktor yang Mempengaruhi Kemiskinan di Provinsi Nusa Tenggara Timur," Universitas Pertanian Bogor, Bogor, 2012.

[12] R. Hatta, and R. Khoirudin, " Analisis Tingkat Kemiskinan di Propinsi NTT: Pendekatan Data Panel," Jurnal Samudra Ekonomi dan Bisnis. vol. 11, no. 2, pp 138150, 2020.

[13] C. Mustika. "Pengaruh PDB dan Jumlah Penduduk Terhadap Kemiskinan di Indonesia Periode 1990-2008," Jurnal Paradigma Ekonomika, vol. 1, no. 4, pp:12-23, 2011.

[14] M. Kuncoro, Otonomi dan Pembangunan Daerah. Erlangga: Jakarta, 2004.

[15] M. Maliangga, E. N. Walewangko. and A. T. Londa, "Pengaruh Kebijakan Pemerintah Kartu Indonesia Pintar (PIP) Dan Kartu Indonesia Sehat (KIS) Terhadap Konsumsi Rumah Tangga Miskin di Kecamatan Dumoga Timur Kabupaten Bolaang Mongondow," Jurnal Berkala Ilmiah Efisiensi, vol. 19. no .01, pp.32-43, 2019.

[16] U. D. Marut. "Aspek Sosial dan kaitannya dengan masalah kurang gizi di kabupaten manggarai, NTT," Jurnal gizi dan pangan, vol. 2 no. 3, pp: 36-43. 2017.

[17] D. W. Hosmer, and S. Lemeshow, Applied Logistic Regression. USA: John Wliey \& Sons, 2000.

[18] L. Anselin, " Spatial Econometrics: Methods and Models. Handbook of Applied Economics Statistics," Marcel Dekker : New York, pp. 237-289.1998.

[19] C. Chasco, I. Garcia, and J. Vicens, "Modeling Spatial Variations in Household Disposable Income with Geographically Weighted Regression," Munich Personal RePEc Archive Paper, no. 1682. 2017.

[20] M. F. Qudratullah. "Misklasifikasi Mahasiswa Baru F Saintek UIN Sunan Kalijaga Jalur Tes Tulis Dengan Analisis Regresi Logistik." Jurnal CAUCHY, vol. 1, no. 4. pp. 175-181, 2011.

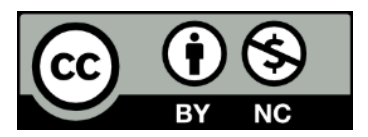

This article is an open-access article distributed under the terms and conditions of the Creative Commons Attribution-NonCommercial 4.0 International License. Editorial of JJoM: Department of Mathematics, Universitas Negeri Gorontalo, Jln. Prof. Dr. Ing. B.J. Habibie, Moutong, Tilongkabila, Kabupaten Bone Bolango, Provinsi Gorontalo 96119, Indonesia. 